\title{
Effect of weather parameters on sporadic incidence of cucumber moth, Diaphania indica (Saunders) (Lepidoptera: Pyralidae) in bitter gourd ecosystem
}

\author{
JAYDEEP HALDER*, DIBYENDU DEB ${ }^{1}$, DEEPAK KUSHWAHA and A. B. RAI \\ ICAR- Indian Institute of Vegetable Research, Varanasi, Uttar Pradesh-221305, India \\ ${ }^{1}$ ICAR-Indian Grassland and Fodder Research Institute, Jhansi, Uttar Pradesh-284003, India \\ (*Corresponding author's E mail-jaydeep.halder@gmail.com)
}

\begin{abstract}
The field experiments were carried out to study the population fluctuation of Cucumber moth, Diaphania indica in bitter gourd and its relationship with different weather variables during Kharif seasons of 2014 and 2015 in Varanasi region. Weekly data on larval population of $D$. indica on bitter gourd were taken through simple random sampling whereas different abiotic parameters were obtained from the meteorological observatory of the institute. The results revealed that the $D$. indica population commenced from $31^{\text {st }}$ SMW. The maximum population was recorded during $38^{\text {th }}$ SMW (in 2014), during $39^{\text {th }}$ SMW (in 2015). During September in both the years. The maximum, minimum and mean temperature, growing degree day, heliothermal unit and evaporation rate showed significant positive correlations with this sporadic pest where as a negative correlation was established with relative humidity, rainfall and wind velocity. A weather based prediction model has also been developed with different weather indices and pest incidence using weekly average value.
\end{abstract}

Keywords: Diaphania indica, bitter gourd, abiotic factors, forewarning model

Cucumber moth or pumpkin caterpillar, Diaphania indica (Saunders) (Lepidoptera: Pyralidae) is a sporadic pest of cucurbitaceous crops especially bitter gourd, cucumber, pointed gourd and gherkin. Light green larvae, with two prominent longitudinal dorsal whitish lines, feed chlorophyll portion of the leaves by webbing them together. Damage is more severe when they feed the reproductive parts of the plants viz., flowers and young fruits. The larvae make characteristic holes on the fruits and feed inside it. The bored fruits become unfit for human consumption (Rai et al., 2014). Though this pest has been reported as the major pest of most cucurbitaceous crops world over (Ganehiarachchi, 1997), in India, particularly eastern part of Uttar Pradesh earlier it was considered as a minor pest of cucurbits. In last couple of years its infestation has become serious and observed in regular manner. Critical observation revealed that its infestation started from August and continued till November/December coinciding with the onset of winter with peak infestation during the September when crops like bitter gourd and cucumber are at their mid reproductive stage. During this period, the damage by this pest was so serious that chemical control was almost inevitable. Farmers of this region often used to apply around 5-7 rounds of synthetic insecticides to control this oligophagous pest. This practices have led to many fold problems like resistance to insecticides, resurgence of target insects and secondary pest outbreak in addition to insecticide residues in food and beverages, contamination of groundwater, adverse effect on human health, and wide spread killing of non-target organisms (Halder et al., 2012, 2013 and 2014).

The insect pest incidence is an outcome of interaction among host, insect and weather over a period of time. Different meteorological parameters viz., temperature, rainfall and relative humidity greatly influence the insect population (Siswanto et al., 2008). With this in view, the present investigation was aimed to elucidate the effect of different weather parameters on the population buildup of $D$. indica in bitter gourd ecosystem and also to develop a weather based prediction model for this emerging pest. This will be useful to take suitable control measures well in advance, thus reducing the excessive and unnecessary usage of insecticides, cost of cultivation as well as environmental hazards.

\section{MATERIALS AND METHODS}

The field experiments were carried out at experimental farm of ICAR-Indian Institute Vegetable Research, Varanasi ( $82^{\circ} 52^{\prime}$ E longitude and $25^{\circ} 12^{\prime} \mathrm{N}$ latitude), Uttar Pradesh, India during Kharif seasons of 2014 and 2015. The experiment site comes under the alluvial zone of IndoGangetic plains having soils silt loam in texture and low in 


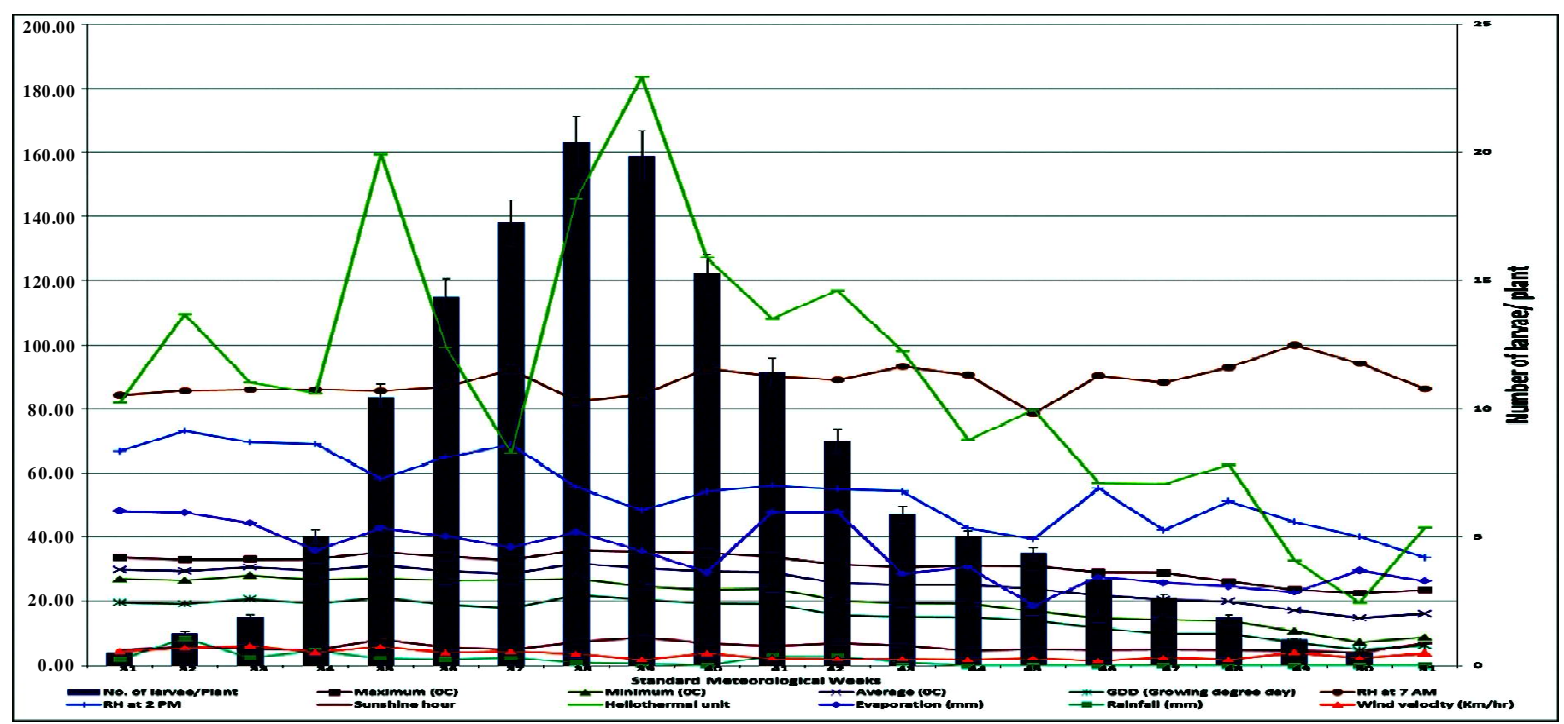

Fig.1 : Mean cucumber moth, Diaphania indica infesting bitter gourd and influenced by mean weather factors of the year 2014 and 2015.

organic carbon $(0.43 \%)$ and available nitrogen $(185 \mathrm{~kg}$ $\left.\mathrm{ha}^{-1}\right)$. Mean weekly meteorological parameters recorded during cropping seasons 2014 and 2015 at IIVR meteorological observatory are presented in Fig. 1.

Seeds of bitter gourd were sown in a plot with plant to plant spacing of $50 \mathrm{~cm}$ and row to row distance $2 \mathrm{~m}$ with three replications during second fortnight of June of both the years. The recommended dose of fertilizers were applied. Hand weeding and irrigations were provided as required and usual crop husbandry measures were undertaken except plant protection measures.

\section{Data recording}

The regular monitoring for the insect incidence and subsequent damage on fruits as well as on tender buds was recorded during morning (in between 10 to $11 \mathrm{am}$ ). Ten randomly selected plants were tagged and data on number of larvae of $D$. indica per plant were counted at weekly intervals and expressed as number of larvae plant ${ }^{-1}$. The data were recorded from just beginning when first symptom of $D$. indica was observed.

The data on weather parameters during the cropping periods were collected from meteorological observatory located in the institute. The weather parameters included are daily maximum temperature $\left(\mathrm{T}_{\max }\right)\left({ }^{\circ} \mathrm{C}\right)$, daily minimum temperature $\left(\mathrm{T}_{\min }\right)\left({ }^{\circ} \mathrm{C}\right)$, average daily temperature $\left(\mathrm{T}_{\text {average }}\right)$ $\left({ }^{\circ} \mathrm{C}\right)$, average day relative humidity at $7.00 \mathrm{am}$ and $2.00 \mathrm{pm}$ $\left(\mathrm{RH}_{\text {day }}\right)$, bright sun shine hour, evaporation $(\mathrm{mm})$, rainfall $(\mathrm{mm})$ and wind velocity $(\mathrm{km} \mathrm{ph})$. The growing degree day (GDD) was calculated by subtracting base temperature $\left(10^{\circ} \mathrm{C}\right)$ from average daily temperature whereas heliothermal unit (HTU) was derived by multiplying GDD with bright sunshine hours (Ghosh et al., 2015). The cumulative value of weather parameters were calculated by adding everyday value since the date of sowing.

\section{Model development}

All the independent variables were plotted against the dependent variable i.e., number of larvae per plant. Since, growing degree day and heliothermal unit are derived from the base temperature were not considered for the final model development. The independent parameters which followed an exponential or power curve pattern are attempted and compared based on AIC (Akaike Information Criterion) (Aka ke, 1974) values. The AIC is expressed as:

$A I C=-2 \ln (l(\tilde{\theta}))+2 q$

Where $l(\tilde{\theta})$ was the model's likelihood i.e. the likelihood of the sample for the values estimated from the model parameters and $\mathrm{q}$ was the number of weather parameters estimated. A smaller value of AIC suggests a better model and thus exponential model was found the best suited in all the cases. Regression diagnostics were also conducted to validate the model. SAS software version 9.3 was used for statistical analysis following the standard procedure.

\section{RESULTS AND DISCUSSION}

It is evident (Fig. 1) that incidence of cucumber moth, D. indica on bitter gourd was started during $31^{\text {st }} \mathrm{SMW}$ in 2014 with 0.75 larva per plant and gradually increased and 
Table 1: Correlation coefficient ( $r$ ) of incidence of cucumber moth, $D$. indica with abiotic factors with pooled data (2014 and 2015)

\begin{tabular}{ll}
\hline Abiotic parameters & Pooled \\
Maximum temperature $\left(\mathrm{T}_{\text {max }}\right.$ & $0.568^{*}$ \\
Minimum temperature $\mathrm{T}_{\text {min) }}$ & $0.562^{*}$ \\
Average temperature $\left(\mathrm{T}_{\text {mean }}\right.$ & $0.600^{*}$ \\
Growing degree day (GDD) & $0.600^{*}$ \\
Relative humidity at 7 am (RH I) & -0.219 \\
Relative humidity at 2 pm (RH II) & -0.050 \\
Rainfall (RF) & -0.145 \\
Sunshine hour (BSS) & 0.230 \\
Heliothermal unit (HTU) & $0.480^{*}$ \\
Evaporation (EP) & -0.136 \\
Wind speed (WS) & -0.038 \\
\hline
\end{tabular}

* Significant at the 0.05 level (2-tailed)

reached maximum population during $38^{\text {th }}$ SMW i.e., third week of September with 24.25 larvae per plant. From fourth week of September onwards its population started declining with lowest 0.25 larvae plant ${ }^{-1}$ was observed during $47^{\text {th }}$ SMW (third week of November) and from last week of November onwards ( $48^{\text {th }}$ SMW) coinciding with winter in this region no pest population was recorded. Similar trend was also followed during 2015. Highest larval population (19.25 larvae plant $\mathrm{t}^{-1}$ ) was observed during $39^{\text {th }}$ SMW (last week of September). However, during 2015 pest incidence extended till $50^{\text {th }} \mathrm{SMW}$ (second week of December) due to delayed onset of winter in the region.

From Table 1 it is evident that maximum, minimum and average temperature had positive and significant correlation with the larval population in both the years and the corresponding correlation co-efficient $(\mathrm{r})$ values were $0.568 *, 0.562 *, 0.600 *$ respectively. Similar observation was also noted with growing degree day $\left(\mathrm{r}=0.600^{*}\right)$ and heliothermal unit $\left(\mathrm{r}=0.480^{*}\right)$. Sunshine had positive but non significant effect on larva population $(r=0.230)$. Singh and Singh (1993) from Varanasi also reported increase in red spider mite, Tetranychus cinnabarinus (Boisd) population on okra associated with period of high temperature.

In contrast, relative humidity at 7 am and $2 \mathrm{pm}$, rainfall evaporation as well as wind speed had negative correlations with pest incidence but correlations were non significant. According to Patel et al. (2010), morning as well as average relative humidity was significantly and negatively associated with larval population of Maruca vitrata. Norris et al., (2002) also recorded that rainfall significantly decreased the number of thrips remaining on the plants and number of rainy days increased, the numbers of thrips on the plants also decreased and the majority of thrips were washed off the plants within 30 minutes.

The stepwise forward selection method of model fitting was followed which begins with no variables in the model and then variables are added one by one to the model, and the F statistic for a variable to be added must be significant with improvement in coefficient of determination $\left(\mathrm{R}^{2}\right)$ of the model. The model thus obtained is given below.

$Y=-66.16+2.22 T_{\max }+1.07 B S S-1.51 W S S+0.36 R H$ $I-0.25 R H I I+0.82 T_{\min }+0.09 R F-0.18 E P\left(\mathrm{R}^{2}-0.79\right)$

It is evident that the maximum temperature, sunshine hour, wind velocity, relative humidity, minimum temperature, rainfall and evaporation had direct influence $(79 \%)$ on distribution and abundance of D. indica on bitter gourd.

It can be concluded that the information so generated from the present study could be useful to predict the population of cucumber moth, $D$. indica, an oligophagous and sporadic pest of cucurbitaceous vegetables, on at any given time and the developed model will be effective to initiate the suitable control practice to avoid the high yield loss.

\section{ACKNOWLEDGEMENT}

Authors are thankful to the Directors, ICAR-IIVR, Varanasi, Uttar Pradesh for providing the necessary research facilities for conducting the experiments.

\section{REFERENCES}

Akaike, H. (1974). A new look at the statistical model identiûcation. IEEE T. Automat. Contr., 19(6): 716723.

Ganehiarachchi, G.A.S.M. (1997). Aspects of the biology of Diaphania indica (Lepidoptera: Pyralidae). J. Natl. Sci. Coun., Sri Lanka. 25(4):203-209.

Ghosh, D., Bhattacharya, I., Dutta, S., Saha, A. and Mazumdar, D. (2015). Dependence of the weather on outbreak of cucumber downy mildew (Pseudoperonospora cubensis) in eastern India. J. Agrometeorol., 17(1):4350.

Halder, J., Rai,A.B. and Kodandaram, M.H. (2014). Parasitization preference of Diaeretiella rapae (McIntosh) 
(Hymenoptera: Braconidae) among different aphids in vegetable ecosystem. Indian J. Agric. Sci., 84(11):14311433 .

Halder, J., Rai,A.B. and Kodandaram, M.H. (2013). Compatibility of neem oil and different entomopathogens for the management of major vegetable sucking pests. Natl. Acad. Sci. Lett., 36(1):19-25

Halder, J., Srivastava, C., Dhingra, S. and Dureja, P. (2012). Effect of essential oils on feeding, survival, growth and development of third instar larvae of Helicoverpa armigera Hubner. Natl. Acad. Sci. Lett., 35(4): 271276.

Norris, R.J., Memmott, J. and Lovell, D.J. (2002). The effect of rainfall on the survivorship and establishment of a biocontrol agent. J. Applied Ecol., 39:226-234.
Patel, S.K., Patel, B.H., Korat, D.M. and Dabhi, M.R. (2010). Seasonal incidence of major insect pests of cowpea, Vigna unguiculata(Linn.) Walpers in relation to weather parameters. Karnataka J. Agril. Sci., 23: 497-499.

Rai,A.B., Loganathan, M., Halder, J., Venkataravanappa, V. and Naik, P.S. (2014). Ecofriendly approaches for sustainable management of vegetable pests. IIVR Teachnical Bulletin No. 53, pp.-15-16.

Singh, R.N. and Singh, J. (1993). Incidence of Tetranychus cinnabarinus (Boisd). (Acari :Tetranychidae) in relation to weather factors in Varanasi. Pestology, 13:18-23.

Siswanto, R. M., Dzolkhifli, O. and Elna, K. (2008). Population fluctuation of Helopeltis antonii Signoret on Cashew Anacardium occidentalle L. in Java Indonesia. Pertanika J. Trop. Agric. Sci., 31: 191-196. 